\title{
Human Resource Management: Paradigm Shift in the Public Sec- tor Banks in India
}

\author{
Shashi Ranjan Kumar Jha ${ }^{1}$, Vishal Anand ${ }^{2}$ \\ ${ }^{I}$ (Assistant Manager, State Bank Of India, UGC NET In Management, UGC NET In Industrial Relations ) \\ ${ }^{2}$ (Research Scholar, IRRDM, MU, Bodh-Gaya, India)
}

\begin{abstract}
Human Resource Management has become the chief component of managing the employees of any industry these days. The same is true for the Indian banking industry as well. This paper highlights the significance of HRM in the Indian Banking industry. An attempt has been made to apprehend the HRM practices adopted by major banks in India. This paper also proposes the potential role HRM is capable of playing in the banking industry. The findings of this paper are based on secondary sources of data.
\end{abstract}

Keywords: human resource, Performance management, skilled manpower, Job rotation, career planning

\section{Introduction}

Human resource management is the backbone of any organization whether it is operating in a manufacturing industry or a service industry. It has been rightly said that among all assets like financial assets, fixed assets, current assets, movable assets, immovable assets or any nomenclatural categorization of assets, Human assets or Human resources are the most important assets. An organization can have all valuable assets in its hand but without human assets it cannot take proper shape. It is as simple as that an organization needs human assets to bring values to the other assets lying in the form of raw stage categorized under different names.

Human resource management is concerned with the people dimension in any organization. Organizations are established by the people and for the people. It consists of people working together through inter relationships and interactions. Organizations are created to achieve different goals. An organization is nothing without resources. If we remove the employees from the organization, there is nothing but a pile of raw material, machines, and physical commodities. Organization consists of the combination of different resources, among which human resource is the superior.

Managing people in an organization is human resource management. Since every organization is made up of people, acquiring their services, developing their skills, motivating them to high levels of performance and ensuring that they continue to maintain their commitment to the organization are essential to achieving organizational objectives. This is true regardless of the type of organization-government, business, education, health or social organizational objectives. Organizational effectiveness depends largely on the performance of people working in organizations. Management's concern to increase the performance of human resources is human resource management. It aims at achieving organizational goals through improvements in the productive contribution of people. It is concerned with philosophy, principles and practices related to human aspects of management. It keeps balance between the goals of organization and the goals of the individual. Human resource management regards people as the most important resource of an organization.

\section{Signifiacance Of Hrm In Banks}

HRM has never been an alien concept for banking industry but there is a general opinion that it has not been handled in the way it should have been handled. Banking industry is witnessing a huge change all over the world particularly in India and for a developing country like India banking industry has a crucial role to play for financial stability and growth of the country. In this age of globalization a country's strength is its financial strength not its military strength.

Human Resource Management is important for banks because banking is a service industry. Capital and technology are replicable but not human capital which needs to be viewed as a valuable resource for the achievement of competitive advantage. Management of people and management of risk are two key challenges which are being faced by the banks. How you manage the people and how you manage the risks determines your success in the banking business. Efficient risk management may not be possible without efficient and skilled manpower. The entire spectrum of HR practice requires revolutionary changes if the banks have to survive. Jack Welch, former CEO of General Electric, has commented "outside of the CEO, HR is the most critical function in any company." 


\section{Major aspects of HRM:}

Acquisition of talent : An organization stands tall only on support of its team members and that is why it is always required to make the organization's image in such a way that it can attract the talented people and not just a bunch of job seekers searching a place for earning bread and butter. HRM plays a vital role in making a service organization like Banks a hot cake among the job seekers. In this present age of globalization there are lots of opportunities among the young generations and among all the career options through best HRM practices Banking Industry can bring some value for itself.

Training and development: Banks are taking some efforts to train their employees so that they can use these in their actual banking environment. So on the job training is the basis of training culture of almost every Banks however sometimes employees are being provided some institutional trainings at their learning centers also. We are also going to face major challenges on the Talent Management front. In coming times, the work force will get complex and there will be a need to juggle a wide variety of people with varied needs and preferences, resulting in an array of relationships between the organization and those who work for it. More than a decade ago, Peter Drucker expressed the need for what he called "non-traditional" work relations: flexible schedules, contract arrangements, virtual teams, etc.

Job Satisfaction/Employee Satisfaction: Employees satisfaction leads to employee's commitment and only committed people delivers the desired results. If an organization does not understand its employees it can never understand its customer.

Performance Management: Performance management is the process through which managers ensure that employee activities and outputs are congruent with the organization's goals. In this bank uses a number of measures and tools for the implementation of performance management system. A longstanding question that most institutions including banks face is the issue of equitable distribution of rewards.

Retention of employees: An organisation may be able to get the most suited people for our work but then the challenge is to retain these people and to develop them. There are several dimensions to this issue such as training/ re-skilling of employees, performance measurement, promotion policy, transfer policy, talent management, communication, etc.

\section{Factors Leading To Dissatisfaction Among Bank Employees}

Workload: Banking industry is operating in a service sector and so as a whole it looks like that it is not a labor intensive sector. But after minute observation it is quite visible that to serve the banking /financial needs of a huge population of India is not easy. Banking has different segment like Retail, SME, International, General operational Banking etc and among all these operational banking and retail banking is much more labor intensive job because through this Banks offer services to a number of people.

Uneven distribution of work at same level: In public sector Banks generally people enter at two stages one is clerical cadre and other is officer Cadre as a Probationary Officer or Direct recruited officers(DRO). They are trained on same platform during their probation but when they work as a confirmed officer they have to deal with different kind of assignments and sometime it happens that same set of officers have to deal with tough assignments always. So HR should take care of all these issues and should actively practice Job Rotation theory to encourage all staff and to ensure that distribution of work is proper.

Salary Structure: Salary structure of Indian Public sector Bank is now not at par with other PSUs and if we compare it with the Central government employees or with State Government employees then we will find that in last one decade Banking sector has not been able to pay their employees at par with the other sector. If this issue is not addressed properly then this sector will not be a preferred destination for the best talent of the country and in this way it will also stop innovative thinking. So it may damage this sector in two ways one that banking job will be less preferred job and other is higher attrition rate.

Changes in employee values: In present scenario new work force has led to introduction of new values, new ideas more expectation from the employer and when these are not perceived by the organization in right perspective it leads to dissatisfaction and affects commitment of the employees.

Wide gap between HR Policies and HR Practices: In almost every Public sector Bank there is HR policies and a separate HR department to cater the needs of their employees but when it comes to delivery part they fail because because line managers lack the desire to implement HRM, they do not have capacity to implement HRM, since they have other meaningful short term operational responsibilities and limited skills and competencies in HRM due to a lack of training. Banking industry needs to give a serious thought to this and they should introduce HR audit system not just on paper but at ground level also. The clerical and up to middle management grade level of supervisory employees of any bank is the main work force on which operational responsibilities lies and their opinion must be taken for better prospect of employees.

Stiff Organizational Hierarchical System: Banks need to come out of its own shelf and its own internal bureaucratic style of functioning. Employees are the internal customer of any organization and so they should be given proper space. Now a day's management expects every thing to be turned upside down but they do not 
strategies things with the actual drivers or potential drivers of that result. The best development of people is through empowerment. People at all levels in the organization must feel empowered. For this, banks need to cut layers of bureaucracy that we have created over the years and adopt effective ways to delegate.

Lack of Enabler Training System: Although Banks are providing training to its employees which employees find very useful. But on a larger scale it has been found that individual focus should be given which can make them more efficient and productive. On the job training is the general trend which almost every Bank follows but it has no value when your job is actually not properly defined and then it becomes a 'mess'.

\section{Intra And Inter Industrial Comparison}

\subsection{Intra Industrial Comparisons of Public Sector Banks and Private Sector Banks:}

During the 2010 to 2020 decade, Nationalized Banks are at the cusp of a unique opportunity - with people retiring in large numbers making it a 'retirement decade', it is the best time to transform the HR processes and implement some new age concepts. This kind of opportunity to transform HR processes is once-in-alifetime window which, if properly utilized, could help our banks take giant strides. On the other hand, those who miss the bus would lag behind. The kinds of HR changes required are a tremendous challenge and opportunity at the same time. Banking industry needs some fresh ideas to make the banks 'future - ready'.

Table: Staff expenses (Payments to and Provisions for employees) of Public Sector Banks versus Private Sector Banks

\begin{tabular}{|c|c|c|c|c|}
\hline \multirow[t]{2}{*}{ Year } & \multicolumn{2}{|c|}{ Public Sector Banks } & \multicolumn{2}{|c|}{ Private Sector Banks } \\
\hline & Staff & $\begin{array}{l}\text { Cost per employ- } \\
\text { ee (Rupees) }\end{array}$ & Staff & \begin{tabular}{|lll}
$\begin{array}{l}\text { Cost } \\
\text { (Rupees) }\end{array}$ & per & employee
\end{tabular} \\
\hline 1998-99 & $8,83,648$ & $\mid 1,67,940$ & $\mid 60,777$ & $\mid 1,69,307$ \\
\hline $2002-03$ & | $7,57,251$ & $2,70,426$ & $\mid 59,374$ & $\mid 3,54,532$ \\
\hline 2003-04 & 7,52,627 & $2,97,903$ & 81,120 & $3,17,308$ \\
\hline 2006-07 & $7,28,878$ & $3,81,449$ & $1,37,284$ & $3,83,439$ \\
\hline $2007-08$ & 7,15,408 & $4,00,611$ & $1,58,823$ & $4,47,920$ \\
\hline 2008-09 & 7,31,524 & $4,72,493$ & $1,76,339$ & $4,83,501$ \\
\hline 2009-10 & $7,39,646$ & $5,55,874$ & $1,82,520$ & $5,16,491$ \\
\hline 2010-11 & 7,57,535 & 7,15,914 & $\mid 2,18,679$ & $\mid 5,63,154$ \\
\hline
\end{tabular}

Public Sector Banks are no longer the major employment provider in the financial market and also that their per employee expenses have gone above that of Private Sector Banks. The staff strength of Public Sector Banks has gone down between 1998-99 and 2010-11 but that of Private Sector Banks have gone up significantly. The per employee expenses of Public Sector Banks have gone above that of Private Sector Banks and today, it is much higher than that of Private Sector Banks. This is despite the fact that pension expenses of PSU Banks are not fully reflected in their staff expenses. One thing is, thus, loud and clear - the competitive advantage in terms of staff costs that we always thought the Public Sector Banks had is no longer there. The absence of the cost advantage coupled with the problem of lower productivity underscore the critical need for urgent HR transformation in Public Sector Banks. Hence, time has come for Public sector banks to pay attention to this critical aspect on which their ability to compete finally hinges on.

\subsection{Inter Industrial Comparisons Public Sector Banks and Other PSUs:}

In today's trans-cultural organization any progressive organization need to follow the trend as quickly and swiftly as it can. Public sector banks need to compare itself with other public sector undertakings in India to address the reasons of attrition among new entrants. For this Banks need to consider some major issues raising resentment among Bank employees viz salary structure, working hours, employee benefit scheme etc. If any organization is offering five days working cultural and that is becoming a new attraction for the present age group of employees then banking organization should also give sincere thought to such types of demand which is emanating from its own people. Employees or 'Human resources' have some common expectation from their employer and to fulfill their expectation an organization must compare its HR Policies not only with its own sector but with the best of any sector. If any organization overlooks criticism within the organization from its own employees then it is quite obvious that organization will stuck in the present situation for a long time which will dent its prospect. The management of Public sector banks needs to compare itself with other PSUs like ONGC, NTPC, SAIL, IOCL, HPCL, GAIL, BPCL, BHEL etc. They should also compare their Balance sheet 
size, profit, ROI, operational expenses, per employee profit etc with that of other PSUs to have a better picture of man management and formulate better policies.

\section{Suggestions To Improve Hr Management In Banks And Cost Cutting Strategy}

Ignorance of HRM results into low productivity, high operational cost, de motivation, and spreads negativity in the organization. Pessimistic view about the sector among the new entrants, increases attrition Rate and increase the tendency of procrastination and decline in organizational effectiveness. Therefore to avoid any of these situations an organization needs to adopt a dynamic as well as long term approach for its own people.

\subsection{Suggestions to Improve HRM in Banks:}

Indian Banking industry has been an important driving force behind the nation's economic development. The emerging environment poses both opportunities and threats, particularly to the public sector banks, as well as the human resource in changing economic and business environment. The first and foremost emphasis needs to be on integrating human resource strategies with the business strategy. Following should be the HR practices in banking perspective.

Quarterly 360 Degree Feedback System through HRMS (Human Resource Management System): In this age of technology quarterly feedback system should be introduced in the banking industry. Feedback taken from the employees through HRMS of every Bank's Portal can pave the way for better HR policies which suits the banking industry or a particular bank. It will bring better Human Resource Techniques specially to cater the needs of Bank employees. HRMS can be the best platform to understand their expectation and it will give them a feeling of participation in the making HR policy of the organization.

Monthly HR Review with Performance Review meetings: Banks have a large network of operational units and it has a huge strength of workforce so it may not be feasible to organize monthly HR review meetings with all staffs simultaneously. Therefore at operational unit level monthly HR review meeting should be called by the line managers to understand the HR related issues of the employees and to develop a feeling of participative management.

Managing Human capital is core concept in the knowledge era: Human capital is the stock of competencies, knowledge, social and personality attributes, including creativity, cognitive abilities, embodied in the ability to perform labour so as to produce economic value. The challenge that most institutions including banks face is realizing this resource to serve its purpose. The future of banking in India is going to be driven by critical elements the most significant among them being human capital and technology and in that order. Knowledge management can felicitate competitiveness of a product significantly; banks can gain strategic competence through creating and managing organisational knowledge available to it. A knowledge network is not to be measured by the extent of its reach and capabilities to communicate, but rather by the extent to which it supports and promotes reciprocity.

For some years now, we all have been hearing, that Indian banks, especially those in the Public Sector will be facing severe crunch of manpower. To visualize that $60-80 \%$ of senior executives, $50 \%$ of middle managers and $60 \%$ of other staff (which amounts to nearly 1.5 lakh personnel) will be retiring in the next 5 years is indeed a daunting challenge. While it is comforting to note that initiatives are being taken to recruit manpower in larger numbers than before, we need to ponder over the requirements of banks in a changed scenario where both technology and soft skills hold the key to ensuring the achievement of the goals set up by the management. Banks would, therefore, need to reorient their strategies with specific reference to HR management so that change to the new environment - which has already taken strong roots - is not only smooth but also well sustained. In the days to come, banks that deal optimally with HR issues such as appropriate talent acquisition and management, career planning, rewards and succession planning, compensation, learning and development, attrition and retention, calibrating skill gaps (including re-skilling and up-skilling) will outperform the laggards.

Knowledge management leading to innovation: Innovation leads the way in all industries and banking is no different. With regard to innovation, Satya Nadella, CEO, Microsoft, in his first letter to the Microsoft employees, observed: "While we have seen great success, we are hungry to do more. Our industry does not respect tradition - it only respects innovation". This is the importance that successful companies give to innovation. We can also consider the case of Whats App! It is amazing to note that a company consisting of 55 persons could acquire an intrinsic value of $\$ 16$ billion in a matter of a few years. Let us understand the innovative capability of the product. It has managed to bring together 400 million users with the help of a smart phone and a simple business plan. Why can't such products be emulated in the banking sector? Banks need to also look at customer oriented innovation. Most of the innovative steps taken by banks in the recent past have a bearing on the profitability of banks, on their own operational improvements, better housekeeping and the like.

Effective Communication: Communication with employees is a vital part of the HR process as it helps enhance transparency in HR practices, thereby imparting credibility to them. When dealing with human beings, it is important to be objective, transparent and non-discriminatory and this must be effectively communicated. The 
employee must say that the management has all the above qualities. The Board must spend time on devising ways and means for this communication lay down appropriate structures for the purpose. All forms of modern communication channels including intranet, corporate e mails, etc. can be adopted to reach out to employees.

Fair Performance Management System: A fair, transparent and objective mechanism for performance management is a must for all banks because an effective Performance Management System is the key to talent management and succession planning.

Focus on Quality of work life and Work life balance: Quality of work life efforts are systematic efforts by organisation to provide workers a greater opportunity to affect the way they do their jobs and the contribution they make to the organisation's overall effectiveness. This concept has now become the core concept of HRM but for Indian banking industry it is still a distant dream. For this banks need to take several factors into consideration like average working hours of an officer of bank and remuneration, number of holidays available to bank employees and employees of other sectors, employee welfare scheme in banks and other PSUs etc. Major players of Indian banking industry needs to focus on QWL aspect as it leads employee satisfaction and improved morale.

Invest in HRM for Employees Delight: HRM is not static in nature because it deals with different set of people, people of different background, generalist, specialist, so in this age of globalization work force diversity has become more important to take care of. An organization tries to bring innovative products to attract new customers, retain existing customers, increase customers loyalty through customers delight in the same fashion our HR department should also bring new ideas for its employees to bring 'Employees Delight'. In any industry especially service industry we use to preach to our employees for "Customer delight" one step ahead of "Customer Satisfaction". It is said that one satisfied customer will bring 10 new customers and one dissatisfied customer may repel 1000 customers. In the same way banking industry needs to devise ways for attracting talent to its fold and propel talent for bringing new heights for this industry.

\subsection{Integration of HR Strategy with Cost Cutting Strategy:}

In most of the organization cost cutting seems to be a new buzz word which is expected to resolve all the problems of any organization. In this age of competition Banks are also no exception in following this trend, today in banking sector profit margin is very thin and to improve the profitability of the company or to survive in the competition banks need to follow this approach. But it must be integrated with HR strategy of the organization. HR managers should identify all HR performance drivers and HR enablers or deliverables which exists within the strategy map, and enhance those factors that can be developed.

HR professional must spend more time and effort for understanding the business environment and the key strategic issues faced by the banks. In banking sector HRM has not expanded its wings and it has just become a operational department engaged in issues like transfer posting, keeping record of leave balances, medical bills etc. HR should have a vision for the organization and people handling the HR department must have that integrated approach for business development along with the organizational development. HR should recognize that there is inadequacies within the organization which can be corrected by better HRM, it is necessary to find out the professional and competent people within the organization to plan and execute the organizational development activities with proper placement of employees. Cost cutting mainly focuses on the demand and supply of physical resources and it can never bring the desired result until the organization manages the demand and supply of human resources.

\section{Conclusion}

Progressive organization can never afford to ignore its human assets in this age of competition. Without human resources, no organization can achieve its goals. Among all the resources in organization, human resource is the most important. It is necessary to bring better processes and policies which make the human resource satisfied and motivated to their works. Line managers are responsible for HRM implementation in Banks since they have to execute the HRM practices on the work floor. However, line managers find implementing HRM practices difficult because line managers lack the desire to implement HRM, they do not have capacity to implement HRM, since they have other meaningful short term operational responsibilities and limited skills and competencies in HRM due to a lack of training. HRM practices can be developed properly, but if line managers fail to implement them successfully on the work floor they are still not effective. The more HR competencies the line managers have and the better they get supported by HR professionals, the more effectively they implement HRM practices. Training of the line mangers for better implementation of HRM practices must be conducted on a regular basis.

Banking industry is nerves and control of any economy and to maintain the proper heart beat of the economy it is necessary to take care of its drivers. Banking industry is one of the few industries which directly impacts the every other drivers of economy for example steel industry, Gas industry, oil refinery, Agricultural industry etc. Any entrepreneurial voyage starts with some human capital and capital and the banking industry 
has the major role to play to give them proper boost. To make Indian banking system stronger efficient and low cost, the industry must lay down some specific standards with regard to operations, strategies and processes, strengthen the prudential norms adopt international benchmarks, manage organisational change and consolidation within financial system and to make it successful HRM functions as the catalyst of transformation. The major concerns of the firm should not be of keeping the immediate operating cost down but to invest for the future. Hence, HRM can work as a glue stick for team build ups and can bring the desired results for the Banks and it can also play a crucial role in nation building process.

\section{References}

[1]. Annual Report 2012-13 Ministry of Labour and Employment, Govt. Of India

[2]. http://www.rbi.org

[3]. http://labourbureau.gov.in

[4]. Organizational Behaviour: Robbins and Sanghi

[5]. Personnel Administration: Paul Pigors and Charles A.Myers 